\title{
A Moderate Reformer: Lefevre d'Etaples
}

Author(s): G. V. Jourdan

Source: The Irish Church Quarterly, Vol. 3, No. 12 (Oct., 1910), pp. 301-311

Stable URL: http://www.jstor.org/stable/30067594

Accessed: 28-06-2016 04:39 UTC

Your use of the JSTOR archive indicates your acceptance of the Terms \& Conditions of Use, available at

http://about.jstor.org/terms

JSTOR is a not-for-profit service that helps scholars, researchers, and students discover, use, and build upon a wide range of content in a trusted

digital archive. We use information technology and tools to increase productivity and facilitate new forms of scholarship. For more information about JSTOR, please contact support@jstor.org.

is collaborating with JSTOR to digitize, preserve and extend access to The Irish Church Quarterly 


\section{A MODERATE REFORMER: LEFEVRE D'ETAPLES.}

THE present article is intended to do no more than recall the memory of one whose name has been suffered to fall into undeserved oblivion. In the more recent of histories his influence upon his own time has been recognized by brief notices. Yet his life work might well attract more attention than it has received, and would no doubt have done so, had it not been that the scantiness of the materials offers serious obstacles to the production of a satisfactory biography.

The name of Jacques Lefèvre d'Etaples (Jacobus Faber Stapulensis) is familiar to French Protestants, who proudly claim him as their first "Réformateur." The sense in which he may be so described cannot be that in which, for instance, the title is accorded to Calvin. He had no hand, like that great man, in the ordering of events or the attainment of results; the most that can be claimed in his behalf is that he fostered and tried to guide the tendencies towards reform which had declared themselves in his day. He lived long enough indeed to see "results," but they were not such as he had hoped for or was disposed to welcome.

Lefèvre was born at Etaples, a sea-port of northwestern France, in 1455. This little town, known as Quantowic in the times of the early Frankish kings, is situated on the right bank of the river Canche. It is usually described as having been "of Picardy." A learned resident of Etaples, however, who has supplied some of the particulars of this paper, asserts that its proper designation at Lefèvre's birth was "on the confines of the Boulonnais."

The commercial activities of the sea-port, which had experienced a long period of neglect, awoke to new life about the middle of the fifteenth century, and once more its markets became thronged with sailors and merchants of many nations. To the cosmopolitan influences exerted on him in his boyhood by so motley a crowd of strangers are, no doubt, due many of the characteristics which displayed themselves in Lefèvre's later life. His faculty of curiosity was, for instance, stimulated by the appearance of so much that was unfamiliar, and his eager 
desire to arrive at the real grounds on which things rested refused to be satisfied with the usual explanations offered by authority. This insistence on authenticated information naturally developed in him an independence of thought and judgement which could hope for little sympathy or recognition in the opening years of the sixteenth century. But to these early surroundings we must attribute, above all, that deeply-rooted conception of the catholicity of the Christian Church which afterwards coloured his teaching so distinctively. When he left Etaples he carried with him a profound and conservative sense of religion which is still a noted trait of the Etaplois. For these people, descended as they are from the diverse races that used to throng the little port, retain in their popular Christian beliefs to-day a strange mixture of pagan notions derived from far-off ancestors.

As the boy showed a capacity for learning Lefevre's parents, who appear to have been in comfortable circumstances, sent him to the University of Paris. Once there he cared so little for anything beyond study that he abandoned to his greedy brothers and nephews his own rights of inheritance.

There is no record of him earlier than I 488-1489. We only know that, in due course, he proceeded to his M.A. degree, and soon after entered into Holy Orders. Whether he ever actually exercised the functions of a priest cannot be ascertained. In the year mentioned 1 he went on his first journey to Italy. From this event must be reckoned his interest in Greek literature. $\mathrm{He}$ never indeed became a Hellenist of note, and it was only the philosophy of Aristotle that had any attraction for him at this time. On his return to his own country he formed the determination to give Aristotle to his countrymen in a purer and more correct form than had hitherto been possible. During the Middle Ages Aristotle was not altogether unknown in Western Europe, but, inasmuch as information concerning him had come through Arabic sources, the works of the Greek philosopher had suffered considerably from the devious routes by which they had reached the mediaeval student.

I Barnaud: Jacques Lefèvre d'Etaples, Cahors, 1900, p. There appears to be some doubt as to whether this first Italian journey ought not to be dated 1492: see Delaruelle, Guillaume Budé, Paris, 1907, p. 47, note. 
The years that followed his return were busy ones for Lefèvre at Paris. He lectured on philosophy and mathematics and published the Logic, Physics and Ethics of Aristotle, which he corrected in accordance with the Greek texts. But if he so delivered himself to the study and teaching of philosophy, he had no idea of permitting abstract speculation to become the goal of his labours. Lefèvre had learnt in his childhood, as he watched the traders in his native place, the practical lesson of drawing from mental qualities some definite advantage or profit. Hence all through life study, whether of philosophy or literature, or of any other department of learning, subserved one end-the good of Christianity. This attitude of mind marked the wide difference between Lefèvre and the scholastic philosophers of his time.

The search after truth in philosophy led him by slow degrees to deep thoughts of holy things. In 1498 he exchanged the study of heathen philosophy for that of the Christian Mystics. For ten years he was immersed in these works of piety. During that time he was resident in the College of the Cardinal Lemoine, where he delivered lectures and had many famous pupils. Of these two deserve particular mention here, as they represented, later on, two parties, two schools of thought, amongst those who sought to reform the Christian religion in France. One was Guillaume Farel, the fiery apostle of militant Protestantism, the precursor, friend and assistant of John Calvin. The other was Guillaume de Briçonnet, Bishop of Lodève, a cultured nobleman, son of a Minister of the Crown who had taken orders and become Archbishop of Narbonne and Cardinal. In all history there are few more pathetic figures than the younger Briçonnet. $\mathrm{He}$ set the high and noble ideal before him of working for the betterment of religion, and of doing this as far as was possible without disturbing the peace of any man. For this he merits the admiration and approval of all good men. But the power to carry out his benevolent designs was wrested from him by the excited zeal of both friend and foe. Moderation and peaceful counsels exposed him to the suspicion of both parties alike. Baffled and disappointed he retired at last from his bishopric of Meaux, overborne by the violence of the partizan spirit, and unfitted by the can- 
dour of his own judgement to use in his defence the weapons employed against himself.

It was not until I 508 that Lefèvre began to devote himself to the exposition of Holy Scripture. From this time to the end of his long life he consecrated all his powers to this labour.

No one was at that time better qualified by circumstances and training to impress on his generation the value of a knowledge of the Bible. As the restorer of the Aristotelian philosophy, ${ }^{1}$ he enjoyed a high reputation in the University of Paris and throughout the learned world. The rôle of a leader was foreign to his cautious and gentle temperament, otherwise he might well have become the centre of the company of brilliant scholars then to be found in Paris, for he exercised over them, undoubtedly, a powerful influence. Moreover, certain advantages accrued to him about I 508 which increased his power and reputation. In the first place, he obtained, though not a monk, a secure residence in the famous monastery of St. Germain-des-Prés. Here he dwelt, not as an inmate subject to rules and restrictions, but as the favoured scholar, the honoured guest of the family that held the Abbacy, the Briçonnets. About the same time also he obtained an introduction to the Court, an event which was to prove of great value to him in later days. That these circumstances combined to impart to Lefèvre's position weight and importance is to be inferred less from the actual records of French history or from anything Lefèvre himself has written than from the place assigned him by German and English scholars of his time, themselves of no mean rank in their own countries.

The first result of the new direction of his studies was the Quincuple Psalter (published by $\mathrm{H}$. Estienne in I 509). It is hard to bestow a sufficiently descriptive title upon this work. It was clearly intended to be a kind of study in Textual Criticism, a science indeed not yet born. The first portion of the book is occupied with the three Latin Versions of St. Jerome, called by Lefèvre the "Gallican," that is, the version adopted in Gaul, the

I Reuchlin's letter to Lefèvre, 31 August 1513, given in Bulaeus, Hist. Univ. Parisiensis, vi. 61, and Herminjard, i. 12 ; Sir Thomas More's lengthy letter of remonstrance to Martin Dorpius, 21 October, 1515, given in Eras. Opera (Leyden) iii. 1896 D,E. 
"Roman," that adopted at Rome, and the "Hebrew," that which was made direct from the Hebrew for Sophronius. These are printed in parallel columns for the purpose of comparison. The second portion contained the Old Latin Version (that which was in vogue before St. Jerome made his versions) and Lefèvre's own revised, or harmonized (conciliatum) version, these two being also printed in parallel columns.

It would be of great interest and value now to know what manuscripts he used. We know from the labours of Robert Estienne in 1540 that there were then many precious codices of the Vulgate in the library of St. Germain-des-Prés. In his Preface to this work, Lefèvre mentions having consulted many ancient, worm-eaten codices, but that is all he says about them.

However, it is abundantly evident that his mind was not so much concerned about the critical part of his task as about the expositions which he appended to the several Psalms. This portion of his work is indeed the most valuable to those who are interested in determining Lefèvre's place in religious history, since from it may pe gathered the reasons which have led historians to class him as a reformer. As a means to stimulate devotion he knows of no instrument more effective than the word of God, and, that the knowledge of it should be undiluted and pure, he rejects the prevalent method of exposition by manifold senses, oftentimes artificial and jejune, and the glosses by which tradition had obscured it. He follows simply what he calls the spiritual sense. According to it the practical value of the Psalms lies principally in the application of each of them to Christ, to His Church, or to Christ's dealings with His Church. Therefore Lefèvre's exegetical method resolves itself into an attempt to emphasize the evangelical element in Scripture and thus to exalt its value as the highest accessible source of spiritual comfort and admonition. Indeed, in the Preface addressed to Cardinal Briçonnet, he draws attention to this as the chief purpose of his labours: "I must beseech Christ, who is the beginning and end of all Psalmody, that it may not only be accepted, but that it may be of service to many to attain happiness." A modern French biographer of his ${ }^{1}$ has discovered-one

1 Barnaud, Lefère, p. 24. 
can hardly avoid the thought that the discovery was the result of a somewhat laborious search-the doctrine of Justification by Faith only in the Expositio Continua of Psalm vi., where Lefèvre says:-" $\mathrm{Da}$ mihi salutem aeternam, non quia dignus sim, non quia meritus sim, sed ob solam miserationem et gratiam tuam." But such expressions of dogma, if ever made deliberately by Lefèvre, are only incidental and never constitute his main preoccupation. He was anxious that men should read the Bible and ponder it, and he strove to enable them to do so from the most profitable point of view. He was not directly concerned with the doctrines they might deduce from it.

In pursuance of the great design, Lefèvre published, in 1512, his notable work, the Latin Commentaries on the Pauline Epistles. Dr. Delaruelle ${ }^{1}$ has remarked in a recent volume on the great Budaeus, that "by his exegetical works Lefèvre precipitated the Reformation," alluding primarily to these Commentaries. The statement finds its justification in the expressed opinions of some of Lefèvre's contemporaries. Martin Luther ${ }^{2}$ (whilst yet the unknown professor at Wittenberg) passed a censure upon the book, because of its intentional deficiency in dogmatical teaching, in a letter of I9 October, 1516 , to Spalatin, and in another of I March, 1517 , to Lange. The censure serves, in Luther's own case, a double purpose. On the one hand it shows the wide diffusion of Lefèvre's influence, and on the other it indicates thus early the attitude he himself was about to assume towards reform. A juster tribute to the value of Lefèvre's book was that implied by Erasmus, when, in defence of his Greek Testament published in 1516, he pointed out that in his edition, so fiercely attacked by hostile critics, he had merely followed in the footsteps not only of Valla but of Lefèvre. ${ }^{3}$ The plea was scarcely accurate. There were fundamental differences between the two books. Lefèvre had obeyed very carefully and circumspectly the rule that had become obligatory in practice from the reign of Charlemagne, of

1 Delaruelle, Budé, p. 54 .

2 De Wette, Luthers Briefe, i. $39,5 \mathrm{I}$; extracts from these two letters are given in Herminjard, 1. $26 \mathrm{f}$.

${ }^{3}$ Apologia prefixed to Novum Instrumentum, $O p$. tom. vi. (Leyden); Ep. to Card. Grimani, ibid. iii. 144, A. 
correcting the text of the Latin Vulgate from Latin codices alone. ${ }^{1}$ So cautious was he that he did not presume even to touch the Vulgate, ${ }^{2}$ but altered only that ancient Latin which St. Jerome himself had revised. Erasmus, on the contrary, disregarding a mere conventionalism altered the Latin Vulgate and that too on the authority of Greek texts, then commonly regarded as heretical.

The divergence between the two books arises in fact from the differences of method pursued by the two authors towards a somewhat similar end. Erasmus aimed at the correction of error, whether in the text of Scripture, or in doctrine, or in the daily lives of Christians. $\mathrm{He}$ did not shrink from pointing out the error or from controverting it. Lefèvre's method was more positive: no less sensitive to the prevalence of abuses, he feared to arouse hostility by stigmatizing them, and confined himself to an inculcation of what commended itself to him as right. $\mathrm{He}$ was a representative of that considerable school which holds that with the restoration of genuine piety errors of discipline and doctrine will disappear automatically and without a struggle.

Ecclesiastical affairs were, however, during these years, taking a course very little likely to respond to Lefèvre's benevolent ideal of peaceful reform. There had been a time when such would have been welcomed; but reform had been refused when submissively prayed for-it was now to be forcibly demanded.

To a certain extent it is also true that Lefèvre's ideal found itself at issue with the strongest current of the age. Nationalities, in the modern sense, were springing into existence and trying their strength, and national tendencies in religion were destined to furnish a powerful impetus to the reformation movement. Nationalism was not however the highest ideal in religion as Lefèvre discerned it. The Church of Christ was not, for him, a denomination either racial or sectarian, but a realization of the brotherhood of man. So vividly was he possessed by this vision that in his Quincuple Psalter he professed himself impatient of such titles as "Church of Rome" or

${ }^{1}$ Scrivener, Intro. to the Criticism of N.T., Camb. 1883, p. 350 ; Smith's D.B., Art. "Vulgate," sec. iv.

2 Lefòvre draws attention to this in his Dedicatory Preface. 
"Gallican Church" in that they obscured, as he held, the glorious truth that there is but one Church, the Church of Christ.

It is worth pointing out here that this catholic instinct, so strongly developed in one who was at once a sincere friend of reform and a pioneer in critical studies, as he understood them, brings Lefèvre into a kinship strangely close with those great French scholars and critics of the present day whose general attitude towards Church unity is on the whole so stmilar. We wonder, sometimes impatiently, why the "Modernists" do not leave the communion of Rome: their steadfastness is attributed sometimes, it is to be feared, to unworthy motives. But the lesson from their life as well as from Lefèvre's is surely that a passion for sincerity and truth in religious teaching and practice does not necessarily involve, and can be maintained quite apart from, that tendency to "split" which has disintegrated and weakened the churches of the Reformation.

There are epochs, however, when counsels of conciliation are not listened to, and Lefèvre's lot was cast in one of them; yet he continued to raise his voice in his own way. In I 522 he published a Latin Commentary on the Gospels, and next year a French translation of the New Testament. Apart from the rough vigour of this work, which appeals still to educated Frenchmen, it presents no notable qualities of style and its importance is mostly due to the fact that it formed part of a noble design whose successful completion could not have been without effect on the course of the Reformation.

For the younger Briçonnet, now Bishop of Meaux, had some time previously linvited his old friend and teacher, Lefèvre, to assist him, as Vicar-General, in raising the state of religion in the diocese. Lefevre had already given his aid in a similar enterprise, but the reformation of a single community, that of St. Germain-des-Prés, was a comparatively simple matter beside the problems furnished by the diocese of Meaux. In this latter undertaking Lefevre enjoyed, at the Bishop's invitation, the help of several of his most trusted pupils, Gérard Roussel, Guillaume Farel, Miohel d'Arande, and this company soon earned the sobriquet of "luthériens de Meaux."

But, in truth, the reforms which Lefèvre projected had nothing to do with Luther. They were simply the logical 
outcome of the principles he had derived from his biblical studies. Indeed Briçonnet chose the very time when these measures were being carried out to issue two Synodal decrees dated 15 October, I523, and a Mandate of 13 December, I523, against the books and doctrine of Luther, and against any wilful disturbance of received Church doctrine. ${ }^{1}$ It is impossible to suppose that the Bishop associated the efforts of his Vicar-General with any tendency towards the Lutheran revolt. Moreover Lefèvre's own Prefaces are equally emphatic.

Although the experiment at Meaux was favourably regarded at Court and won the express approbation both of the king, his mother and his sister, it was from the beginning doomed to failure. Since 1512, when his work on the Pauline Epistles appeared, Lefèvre had been earning the growing suspicions of the Theological Faculty at Paris. Recent events in Germany had accentuated their feeling of distrust, and the practical reforms initiated at Meaux brought it to a head. But so long as royal favour shielded Briçonnet no step could be taken against one who enjoyed his protection. When however King Francis was made prisoner at Pavia (1525) and led as a captive to Madrid the opportunity occurred, and Lefèvre's vernacular translations were condemned by the Sorbonne. He was even summoned to answer to a charge of heresy, and would undoubtedly have been condemned had he not, by the advice of his patron, succeeded in making his escape to Strasburg.

The King on hearing, in his Spanish prison, of these proceedings was deeply concerned, and wrote to the Parliament of Paris reserving the case to his own decision until such time as he should be at liberty to deal with it. ${ }^{2}$ Being released the following year he recalled Lefèvre from exile and showed his confidence in him by attaching him to the Court and subsequently appointing him tutor to the Royal children.

In this position he remained for a few years unmolested.

His work as a reformer was now at an end-at least its active aspect had no longer scope for exercise, though he carried on the biblical translations which embodied his ideals. And his enemies were by no means satisfied.

1 Herminjard, i. 153-158, 17 1-172.

Ibid. $401-403$. 
The year 1529 brought a warning that he was still in danger. In that year his friend, Louis de Berquin, a nobleman of Artois, like himself a moderate reformer, a favourite at Court and a protégé of Briçonnet, was arraigned for heresy by the watchful foe, condemned and burnt, with scandalous rapidity, in a single day.

Immediately his friend was dead the executioners fixed on Lefèvre as their next victtim, and the loss of the King's favour in 1530 would unquestionably have sealed his fate had not the King's sister Marguerite, now Queen of Navarre, carried him off to her Court at Nérac.

Here for the remaining six years of his life he lived in peace, a mere spectator of the ecclesiastical turmoils developing on every side. But his ideals, which for one short period only he had been permitted to put in practice, had failed disastrously to commend themselves to his contemporaries. Henceforth it was his lot to behold his work pass into the less judicious hands of his pupils Farel and Toussaint. These impetuous disciples may have displayed more ardour, more vigour, than he had shown, but, handling doctrine without caution and ceremonies without forbearance, they soon outraged the religious sentiments of many who had not been averse from a temperate reform, and by driving them into the ranks of reaction hardened the opposition between the old and the new.

Lefèvre lived to see the neighbouring Church of England repudiate the papal jurisdiction as a first step towards domestic reformation. The year of his death, I 536, witnessed also the death of Erasmus and the début of Calvin at Geneva. His passing then marks the period at which parties crystallized, and the prospect of conciliation faded so that an overt separation became inevitable.

The interest of Lefèvre's career does not centre entirely in itself. It furnishes, as we have already hinted, some materials for a historical parallel of present-day importance; though one would fain hope that the outcome of the contemporary problem will reach a higher level of achievement than its sixteenth century predecessor attained. There died in Paris so lately as IgOI, at the age of 72, an Irishman who, as professor of theology at St. Sulpice for 32 years, did for the French clergy of the nineteenth century a work analogous to that which Lefèvre attempted for the clergy of the sixteenth. There is not space at the 
conclusion of an article to deal with the career and influence of Father Hogan. Suffice to say that he combined an earnest loyalty to the unity of the Church with an enlightened confidence in the competency of critical studies to impart new meaning to the Bible and in consequence a renewal of energy to the Faith. Among his more distinguished pupils are Mgr. Mignot and Mgr. Battifol.

If Lefèvre could have come to life again in our own age, and possessed himself of the outlines of the critical problem as it presents itself to us, he, whose constant aim it was to interpret positive truth to his own generation, might well have associated himself with the ideals which his great successor expressed as follows:-

"Divine truth, as we find it in the teaching of the Church and the Schools, wears a robe of human origin, which serves at once to reveal and to conceal the reality. It presents itself to us in the Bible enveloped frequently in the most diverse Oriental metaphors. We encounter it in the Fathers draped in the mantle of Greek philosophy. It appears anew in the Schools of the Middle Age beneath the armour of Aristotelian dialectic. But none of these vestments is essentially necessary to it. They are only the variable accidents which reveal the hidden substance. To reach the substance itself; to contemplate the reality as closely as possible, shorn of every metaphor, freed from everything which is system only; to remove the anthropomorphic images in which men have accustomed themselves to clothe God and all that is divine; to contemplate the mysteries of the Faith apart from the terminology of the Schools-such is the first result of an earnest and serious study of Christian doctrine."

Is this study destined to be pursued in the twentieth century to an issue more fruitful in doepening and unifying Christian life than that which rewarded its tentative beginnings three hundred years ago?

G. V. JOURDAN. 